\title{
Article
}

\section{The photograph: Tourist repsonses to a visual interpretation of a disaster}

\author{
Wright, Daniel and Sharpley, Richard Anthony john \\ Available at http://clok.uclan.ac.uk/20837/ \\ Wright, Daniel ORCID: 0000-0001-9976-5799 and Sharpley, Richard Anthony \\ john ORCID: 0000-0002-2135-3206 (2017) The photograph: Tourist repsonses \\ to a visual interpretation of a disaster. Tourism Recreation Research, 43 (2). \\ pp. 161-174. ISSN 0250-8281
}

It is advisable to refer to the publisher's version if you intend to cite from the work. http://dx.doi.org/10.1080/02508281.2017.1409921

For more information about UCLan's research in this area go to http://www.uclan.ac.uk/researchgroups/ and search for < name of research Group>.

For information about Research generally at UCLan please go to http://www.uclan.ac.uk/research/

All outputs in CLoK are protected by Intellectual Property Rights law, including Copyright law. Copyright, IPR and Moral Rights for the works on this site are retained by the individual authors and/or other copyright owners. Terms and conditions for use of this material are defined in the policies page.

\section{CLoK}

Central Lancashire online Knowledge www.clok.uclan.ac.uk

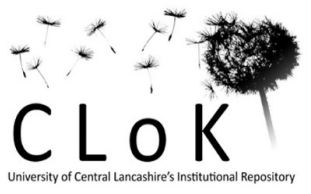


This is a pre-proof corrected manuscript, as accepted for publication, of an article published by Taylor \& Francis Online in Tourism Recreation Research, Available online: 06 Dec 2017. Available online:

http://www.tandfonline.com/doi/full/10.1080/02508281.2017.1409921

PLEASE REFER TO THE FINAL VERSION FOR CITING PURPOSES

The photograph: Tourist responses to a visual interpretation of a disaster

Daniel Wright*

University of Central Lancashire, $U K$

dwright3@uclan.ac.uk

and

Richard Sharpley

University of Central Lancashire, UK

rajsharpley@uclan.ac.uk

*Lead author 


\begin{abstract}
Photographs have long been used as a means of interpretation at museums and other tourism attractions, including dark tourism sites. Typically, such photographs are documentary, recording or depicting subjects relevant to the theme of the site. Less common, however, is the use of respesentational or artistic photographs, and little is known about their effectiveness as interpretation tools. This paper address this gap in knowledge. Based on research in L'Aquila, Italy, the site of a major earthquake in 2009, it explores the responses of tourists to a photograph interpreting the disaster displayed in the city centre. It reveals that the photograph is a highly effective form of interpretation, connecting tourists with the human dimension of the disaster, although the provision of background information on the photograph would enhance the tourists' experience.
\end{abstract}


The photograph: Tourist responses to a visual interpretation of a disaster

Keywords: Disaster tourism; interpretation; photography; representation

\section{Introduction}

On 6 April 2009, L'Aquila, the capital of the Abruzzo region in central Italy, was struck by a powerful earthquake. Much of the city's historic centre was destroyed or severely damaged, 308 people lost their lives with a further 1500 injured, and the majority of the population was made homeless. It was not, however, the first earthquake suffered by the city, a significant number having been recorded throughout its history. Nevertheless, it was distinctive for two reasons. First, it was considered an Italian rather than a L'Aquilan disaster; national resources were provided (at least initially) to support a recovery process that has since proved to be slow and widely criticised (Contreras, Blaschke, Kienberger \& Zeil, 2014). And second, the city almost immediately became a disaster tourism destination. According to Flamminio (2009), within days of the earthquake tourists were observed taking photographs of the ruins whilst a subsequent report (InAbruzzo, 2009) revealed that L'Aquila had become popular amongst tourists. Suggesting that the earthquake had achieved what the regional tourism authorities long failed to do in establishing the city as a popular tourist destination, the report emphasised that visitors were attrati dal'lorrore della città distrutta (trans. 'attracted to the horror of the destroyed city').

In addition, the destruction caused by the earthquake was recorded in its immediate aftermath by local professional photographer Roberto Grillo, whose images were published in a book that sought to both commemorate the victims and warn of the need to prepare for such disasters in the future (Grillo \& Vitturini, 2009). Grillo went on to document the consequences of the earthquake for the people of L'Aquila, producing interpretative images of their loss and suffering that were published in a book entitled The Ethics of Pain (Grillo, 2012). One photograph from this collection, depicting the loss of a father and son whose wife/mother and daughter/sister died in the earthquake, was one of a small number of images subsequently displayed prominently on a main street in L'Aquila (see Figures 1 and 2).

The photograph was located on Corso Vittorio Emanuele II, a street connecting two central piazzas, or squares, within the historical centre, frequented by locals and tourists. At one, Piazza Battaglione Alpine, touristsogather to visit Forte Spannolo, a Renaissance castle 
built in the $16^{\text {th }}$ Century, and the Fontana Luminosa, a fountain dating back to 1934 . Nearby on Corso Vittorio Emanuele II are a couple of cafes which opened after the earthquake, where tourists and locals often stop on the walk to Piazza Duomo. Here is the partially-ruined 18th-century church Santa Maria del Suffragio (commonly called the church of Anime Sante - Blessed Souls). Roberto Grillo's image was placed on Corso Vittorio Emanuele II (closer to Piazza Duomo, near the cafes, hence in a location passed by many tourists.

The photograph was, and remains, not only a stark and controversial reminder of the tragedy of the earthquake but also, significantly, a focal point for tourists who continue to visit the city to gaze on its still to be reconstructed centre. That is, as documented elsewhere (Wright \& Sharpley, 2016), for visitors to the ruined city there were initially no specific places where the human story of the earthquake could be told or where the suffering of the community could be contemplated; they were left to wander directionless around the ruins, witnessing the destructive force of the earthquake but lacking any means of comprehending its consequences for the city's inhabitants. Thus, the photograph, as a manifestation of what Uzell (1992) refers to as 'hot' interpretation, offers tourists the opportunity to engage at a human level with the disaster that befell L'Aquila.

The use of photographic images to record 'dark' events, from natural disasters to wars, genocide, murders and famines, is almost as old as the practice of photography itself, although this was of course predated by the production pictorial representations of the 'danse macabre' from the Middle Ages onwards (Oosterwijk, 2004). Trachtenberg (1985: 1), for example, claims that the American Civil War (1861-65) was the 'first significant crisis in modern history to occur within the memorializing gaze of a camera', since when what Berger (2013: 30-33) describes as 'photographs of agony' have become a powerful and ubiquitous means of not only reporting conflict, death, atrocity and suffering but also arousing an affective response - horror, shock, outrage, guilt - amongst viewers (Butler, 2005; Sontag, 2004). More specifically, photographs have also become widely utilised as an interpretative medium at dark sites and attractions, that is, at places of or associated with death and suffering to which tourists are drawn in ever-increasing numbers (Lennon \& Foley, 2000; Sharpley \& Stone, 2009). One widely documented example is the display of numerous photographs of prisoners at the Tuol Sleng Museum in Phnom Penh, Cambodia (Hughes, 2008; Williams, 2004) whilst the Rwandan Genocide of 1994 is graphically represented in images of victims at the Kigali Genocide Memorial (Friedrich \& Johnston, 2013) yet, across the entire spectrum of dark tourism attractions (Stone, 2006), photographs are inevitably employed as a form of interpretation. 
Typically, such photographs are presented as records or documentary evidence. That is, they are considered to provide a 'true' or realistic record of an event and, as Edwards and Mead (2013: 21) suggest, museum 'displays often mobilize photographs for their assumed immediacy, directness, and unmediated inscription'. Indeed, as Wells (2015: 19) suggests, "the simultaneous "it was there" (the pro-photographic event) and "I was there" (the photographer) effect of the photographic record of people and circumstances contributes to the authority of photographs' although, as discussed shortly, critics have long debated the mediating role of the photographer in the creation of allegedly factual images (Sontag, 2008). At the same time, the selection (or non-selection) of images to be displayed injects an element of subjectivity and dissonance into the visual narrative presented at dark sites (Ashworth \& Hartmann, 2005; Sharpley, 2009). In contrast, less typical are photographs which are, in a sense, pseudo-realistic or combine reality with art - in Grillo's photograph that inspired the research in this paper, for example, the subjects are actual victims of the earthquake, but the image itself is an artistic interpretation of their loss. Thus, a question that arises is: how effective or, indeed, appropriate is an 'artistic' image, such as the one produced by Grillo, in interpreting a disaster? Or putting it another way, in contrast to more factual documentary-type photographs, can such an image better convey a sense of the loss and suffering experienced by the victims of a disaster amongst tourists who subsequently come to gaze upon it?

The purpose of this paper is to address this question; that is, it sets out to consider the extent to which an explicitly 'artistic' photograph is a more effective interpretive tool than documentary images at sites of disasters. Drawing on research undertaken in L'Aquila in the summer of 2015, it considers the responses of tourists to Grillo's photograph, exploring in particular the extent to which it enhances their understanding of the disaster and the local community's experiences. In so doing, it contributes an additional dimension to the dark tourism literature; focusing on the interpretative or mediating role of photographs at dark sites, it addresses an issue that until recently (see, for example, Lennon, forthcoming) has attracted surprisingly limited attention. First, however, is important to establish the broader context of the research by introducing briefly the phenomenon of disaster tourism before going on to consider the potential role of photographic images in mediating between the tourist / viewer and the event.

\section{Please insert Figures 1 and 2 about here please}




\section{Disasters and disaster tourism}

Disaster tourism may be defined succinctly as tourism to places that have been affected by or are sites of a disaster (Kelman \& Dodds, 2009). Such a broad definition, however, not only embraces different purposes of travel to disaster sites, from providing voluntary humanitarian assistance (Mostafanezhad, 2014; Van Hoving, Wallis, Docrat \& De Vries, 2010) to simply gazing on the disaster (Blom, 2000; Shondell Miller, 2008) but also blurs the distinction between disaster and other forms of tourism. For example, Pompeii is undeniably a disaster site yet attracts visitors with a variety of historical, archeological or cultural interests. Hence, a more precise understanding of disaster tourism is required.

Disasters are, according to Barkun (1974: 51) 'perhaps easier to recognise than ... to define'. Consequently, numerous definitions adopting a variety of disciplinary approaches are offered in the relevant academic and professional literature (von Vacano \& Zaumseil, 2013), whilst Quarantelli (1985) suggests seven perspectives on studying disasters. The key point, however, is that the actual event is not a disaster; rather, it is the degree of its impact on society that defines a disaster as such. In other words, it is the vulnerability of society to a particular event that transforms it into a disaster. Hence, a disaster may be defined as 'a serious disruption of the functioning of a community or a society involving widespread human, material, economic or environmental losses and impacts, which exceeds the ability of the affected community or society to cope using its own resources' (UNISDR, 2009: 9). That is, a disaster is an extraordinary event, the consequences of which not only demand external assistance and resources for recovery (Tierney, Lindell, \& Perry, 2001) but are typically measured in its human cost. And it is that human cost, often a relatively significant number of deaths and injuries, that serves to transform a disaster into a tourism attraction or at least a potential attraction, for not all disaster sites are immediately accessible to tourists.

Nevertheless, modern history is replete with examples of disaster sites becoming tourism destinations, from crowds flocking spontaneously to see the burned-out wreck SS Morro Castle at Asbury Park, New Jersey in 1934 (Thomas \& Morgan-Watts, 1988) or the crash site of Pan Am 103 at Lockerbie in Scotland in 1988 (Frew, 2017) to the more organised tourism in New Orleans following Hurricane Katrina (Gould \& Lewis, 2007) and in Christchurch, New Zealand after the 2011 earthquake (Coats \& Ferguson, 2013).

It is for this reason that disaster tourism may be categorised as a form of dark tourism. A term that remains contested (Light, 2017), dark tourism is broadly defined as 'visitation to 
places where tragedies or historically note-worthy death has occurred' (Tarlow, 2005: 48) or, more generally, as 'the act of travel to sites associated with death, suffering and the seemingly macabre' (Stone, 2006: 146), dark tourism is a concept that has attracted increasing academic attention since it was first proposed some two decades ago (Foley \& Lennon, 1996: Lennon \& Foley, 2000; Sharpley \& Stone, 2009). A full discussion of dark tourism is beyond the scope of this paper (see Light, 2017 for a comprehensive review) but it is important to emphasise that, despite the attraction of death being a common factor, disaster tourism in particular is, as Rojek (1997: 63) observes, 'analytically distinct' from dark tourism more generally.

Most significantly, disaster tourism is, in a sense, a temporary phenomenon. That is, disaster tourists may be considered those who travel to gaze on the consequences of a disaster only for as long as those consequences remain in evidence. Once damaged buildings have been repaired or reconstructed, or wreckage has been recovered and removed, the disaster becomes historical, a past event. Hence, Kelman and Dodds (2009: 274) argue that disaster tourism involves only 'travel for leisure to witness the disaster response and disaster recovery' periods. In some cases, those periods may be very short whereas, in other cases, such as at L'Aquila, the recovery period may last a number of years. Either way, however, when the site subsequently becomes a place of commemoration, pilgrimage or more general historical interest (Logan \& Reeves, 2008; Sion, 2014), it then may be thought of more broadly as a dark tourism destination.

In addition, in contrast to established, formally organised and interpreted dark tourism sites, disaster sites are distinctive in that visitation is relatively immediate, spontaneous and unmanaged. In other words, although as noted above tourism to some sites may become to some extent organized, as at New Orleans and Christchurch, disaster tourism is typically not framed within a formal tourism sector. As a consequence, the disaster tourist experience is not directed, controlled or mediated. The immediacy of disaster tourism also suggests that there is some currency in the argument that tourism to disaster sites is essentially 'morbid' (Blom, 2000); that is, it is defined to some degree by a fascination in death, by voyeurism (Schaller, 2007) or schadenfreude. Nevertheless, such claims have been increasingly challenged, with research demonstrating that tourists visit dark sites for a wide variety of purposes (Raine, 2013; Sharpley \& Friedrich, 2016), whilst Kelman and Dodds (2009: 276) identify a number of motives including empathy, guilt, education and remembrance. Thus, given the nature of disaster tourism, there is evidently a need to provide some form of interpretation of the disaster, some means of facilitating tourists' understanding of it. 
Photographs, such as those at L'Aquila, are one means of interpreting a disaster although, as the next section considers, different forms of photography may convey different meanings or elicit different responses.

\section{Photography: realism or representation?}

Photography is a ubiquitous modern phenomenon; as Edwards (2006) suggests, it is difficult to imagine a world without photography (though such a future world is depicted in a novel by Bornefeld, 1996). Not only are photographs everywhere, conveying messages that fulfil a variety of purposes, from informing or persuading to creating memories, but also the practice of photography is becoming increasingly fundamental to contemporary social life. Indeed, the digital revolution in photography and, in particular, smart phone camera technology has challenged traditional understandings of the social role of photography (Bourdieu, 1996). Epitomised, perhaps, by the concept of the 'selfie' (Holiday et al., 2016), digital photo-taking and on-line sharing have fundamentally transformed the practice, meaning and social role of photography (Gye, 2007; Van House, 2011) both generally and in the specific context of tourism (Haldrup \& Larsen, 2010).

It is not surprising, therefore, that photography has long been explored in the literature (la Grange, 2005; Wells, 2003). At the same time, given the diversity of photographic forms and practices, it is also unsurprising that the photography literature is equally diverse and eclectic, from historical accounts from either scientific, aesthetic or social scientific perspectives to discussions of specific photographic genres (for example, fashion, advertising, sport, war/conflict) and practices, the latter of course including tourist photography. Interestingly, the study of tourist photography is concerned primarily with understanding how and why tourists take photographs and its relevance to the tourist experience (Scarles, 2009; StylianouLambert, 2012), whereas the focus of the photography literature more generally is on the photograph itself, its purpose, meaning and significance. Moreover, a key theme within the broader photography literature, and one which is of particular relevance to this paper, is the extent to which a photograph on the one hand presents reality or a true record of something or, on the other hand, is representational or an interpretation - that is, an art form (Bate, 2016).

The arguments underpinning the reality-representation (or document-art) debate are numerous (see for example Edwards, 2006). Fundamental to that debate, however, is the very nature of photography itself or, more precisely, the manner in which a photograph is produced. In essence, a photograph is, as Berger (2013: 19) explains, 'an automatic record 
through the mediation of light of a given event'. In other words, the camera records what it 'sees' at a particular moment, the determining factor being not what is being photographed but the moment at which the photograph is taken. Thus, as Sontag (2008: 11) suggests, photography is 'essentially an act of non-intervention'; a disconnect exists between the photographer and the camera as an unthinking 'instrument of recording' (Price, 1994: 4) and, hence, a photograph merely documents or records what is seen or, in some cases such as astronomical photography, what to the human eye is unseen. Indeed, much of the early fascination in photography was its ability to record the 'optical unconscious' (Benjamin, 1972: 7, cited in Wells, 2015: 21).

Much photography is, of course, concerned with providing documentary evidence, whether of identity (passport photographs), significant family occasions (holidays, weddings) or newsworthy events; such photographs are used to inform, to act as a memento, to educate, to shock. And, in most cases, the significance of a photograph lies in the fact it records something that, for the photographer, is worth recording (Berger, 2013: 18). But it is that involvement of the photographer that challenges the 'truth' of a photograph as an impartial record of reality. The camera records, but the photographer chooses what to record (or not record) and how to record it. Moreover, the ability to manipulate the image, particularly in the digital era, now means that 'in according authority to pictures, we are more likely to question the circumstances under which photographs have been made, their source, the status of the photographer, and the purpose for which they have been made (Wells, 2015: 18).

At the same time, photographers have long sought to distance themselves from photography's technological foundations, attempting to inject a degree of creativity (or art) into the technical process of capturing an image. For example, the pictorialist movement emerged in late nineteenth century photography whilst, by the $1930 \mathrm{~s}$, there was 'the more universal presumption that photography could function as art' (Nickel, 2001: 549). By the 1970s, as Robins (1984: 213) observes, 'the photograph, instead of being presented as a depiction of reality, was now something created to show us things that were felt rather than necessarily seen'; that is, more as a representation as constructed by the photographer than a 'straight' document.

Significantly, such a transformation in style has been evident in what are referred to above as in 'photographs of agony', particularly in war / conflict photography. Reflecting in part a world saturated with and, consequently immune to documentary-type images of human tragedy and suffering (Sontag, 20045; 2008), in part the constraints increasingly imposed on photojournalists in war zones (Wells, 2015: 86), conflict is increasingly interpreted though 
photographs not of combatants but of the outcomes of conflicts, of ruined buildings, scarred landscapes and so on. As such, they bridge the divide (if such a divide has ever existed) between realism and representation and photography; rather than presenting a record of tragedy and suffering, of war and disasters, they offer images to which the viewer must bring their own knowledge, understanding and interpretation (Batchen, Gidley, Miller \& Prosser, 2012).

Roberto Grillo's photograph considered in this paper adopts this alternative style of recording a tragedy. It is a constructed image and, hence, not a 'true' record, yet it interprets a real tragedy suffered by the subjects in the photograph. And it was the photographer's intent not simply to document the tragedy of the earthquake, but to create an image that would provoke a response:

My motivation is that people who have lost loved one already feel as if they have been abandoned; therefore; I want to reawaken their consciences... If and how they engage with and interpret [the photograph] will be dependent on their own personal experiences and motives. But the message the photograph portrays is strong, is true and, importantly, is real. (Roberto Grillo, personal comment)

Thus, the purpose of the research now discussed below was to explore how tourists in L'Aquila responded to Grillo's photograph as an interpretation of the disaster that befell the city.

\section{The Research: Study methods}

The research for this study was undertaken in L'Aquila in the summer of 2015. In order to identify potential participants, the researcher (the first author) initially observed tourists as they walked past the photograph where it was displayed in the city centre; some exhibited active engagement with the photograph, stopping to look at it, whilst others were more passive, glancing more momentarily at it. Once they had moved on from the photograph, tourists were then approached and, on the basis of their ability to communicate in either English or Italian, were asked if they were willing to participate in a short interview exploring their opinion of and response to the photograph. All participants were also asked if they had seen the photograph previously and none of them had. 
Reflecting to the circumstances of the research, convenience sampling, also referred to as opportunistic and availability sampling, was employed (Brotherton, 2015; Long, 2008, Mason, 2014; Long, 2008). This method of sampling is considered non-probability (or nonrandom sampling) and, consequently, no prior inclusion criteria were considered in the selection of participants. A total of twenty street interviews, each lasting between 10-15 minutes, were completed (see Table 1 for a list of respondents). Owing to nature of the topic, participants were clearly informed of the purpose of the research and all consented for the interviews to be digitally recorded using a dictaphone. They were made aware that their comments, age and nationality would be shared in the research findings but that anonymity would be maintained. The interviews were conducted in either English or Italian, and were subsequently transcribed, translated as necessary, and subjected to thematic analysis, an effective means of identifying, analysing and reporting patters (themes) within the data data (Braun and Clarke, 2006). Semi-structured interviews were employed as a flexible and reliable method of permitting discussions to evolve according to each participant's reflections on and responses to the photograph whilst allowing the researcher to obtain data that met research objectives (Gillham, 2005).

\section{Table 1 about here please}

\section{The Research: Tourists' responses to the photograph}

As noted in the introduction to this paper, the broad purpose of this research was to explore tourists' responses to a photograph by Roberto Grillo, located in the center L'Aquila, that portrays the personal loss suffered by a friend during the earthquake that devastated the city in 2009. More specifically, the research sought to identify whether the photograph, interpreting one family's loss, was an effective means of conveying a sense of the disaster suffered by the city; that is, whether it facilitated affective engagement on the part of tourists with the human tragedy of the earthquake. As such, respondents were asked to describe what they thought about the photograph, and whether it helped them understand the effects of the earthquake on the city and its population. They were also asked specifically how Grillo's representational image compared with more traditional documentary-type pictures of earthquake-damaged cities.

A number of clear themes emerged from the research. First and foremost, there was a clear divide between the responses of those tourists who engaged positively with the photograph and the smaller number (four respondents) who demonstrated more superficial or passing 
interest in it although, as discussed below, both groups raised a similar issue. Interestingly, it was only international tourists who engaged less with the photograph; conversely, some domestic tourists (perhaps inevitably) reflected on the wider context of the national response to the disaster. A number of common themes arose during the interviews with those who responded positively, as follows:

\section{i. The human dimension of the disaster}

Many of the respondents explained how the photograph brought home to them the human dimension of the disaster, something they did not experience from more typical documentarytype images. As one explained:

I remember pictures of the earthquake in the newspapers, some years ago, when it happened... the ruins of houses, collapsed churches, cars under rubble. It looked terrible... and you can still see it today. But those pictures, they were no different from lots of pictures of other disasters in other places, pictures you see everywhere. You can't connect with them, they are just pictures of ruined buildings.... But this one is different...it says something... (Participant 6)

Similarly, another respondent summarised an opinion commonly expressed in the interviews:

Today we see photos everywhere, in magazines, newspapers, on the Internet, of disasters, earthquakes, hurricanes, floods... but there are too many; they don't mean anything anymore. It's hard to feel anything, to understand. These things seem distant, just a picture. (Participant 20)

In contrast, the photograph in L'Aquila elicited a more empathetic reaction amongst respondents, encouraging them to look beyond the physical destruction caused by the earthquake as depicted in documentary-type images to think about its consequences for the city's inhabitants. According to one respondent:

When I look at this photo, it makes me think about the people who lived here. It makes me think of their tragedy, the people who lived this tragedy. It is important to recognise the people of this city, and in this photo we have a story of people. This makes it much easier to establish a connection, meaning and to try and allow me, as a tourist, to understand the challenges, the difficulties that the local community have experienced. This photo allows me to contemplate the confrontation between humans and nature. (Participant 1) 
For another, seeing the photograph gave more meaning or significance to their visit, particularly as they were gazing on the effects of an earthquake that was, in effect, now a historic event. Not only was there temporal distance between the tourists and the disaster but also, consequently, a perceived emotional distance which the photograph helped to bridge:

Earlier on, when walking around the city, considering how many years have passed, the people who lived here, the suffering and distress that took place, for us it is very difficult to image how hard it must have been. Just walking round you can begin to feel and imagine the pain, the damage to the structures, the buildings, its overwhelming. But then you see an image like this, it brings you closer to the people. After all, we can relate more to the suffering of people than buildings. (Participant 4)

Or as another put it simply:

Just walking past and you can see all these ruins and in areas where there is construction taking place, and you think how people would have to leave, maybe with nowhere to go. This image helps you to connect with the people. (Participant 8)

In other words, for many of the tourists in this study the photograph provided, in a sense, a bridge between their emotions and the disaster in L'Aquila; that is, rather than gazing perhaps dispassionately on the ruins of the city, the photograph emphasized the human element of the disaster, stimulating emotional responses on the part of the viewer Responses such as these are not uncommon amongst visitors to some dark tourism sites, particularly those sites towards the darker end of Stone's (2006) spectrum. Research has consistently demonstrated that, rather than having have shallow, voyeuristic experiences as some claim (Schaller, 2007), visitors to such sites report a variety of cognitive and affective experiences, from learning and understanding (e.g. Brown, 2014; Thurnell-Read, 2009) to feelings or sensations which, in one way or another, connect the visitor emotionally with the site and the victims (e,g. Chronis, 2012; Yan et al, 2016). Specifically, for example, it has been found that visitors to the Genocide Memorial in Kigali, Rwanda, were most moved by photographs of child victims of the genocide (Sharpley \& Friedrich, 2016), whilst the numerous photographs of victims at the Tuol Sleng Prsdion in Phnom Penh similarly elicited powerful emotions responses amongst visitors (Hughes, 2008). Generally, however, the literature reveals that here is no consistency in the nature of tourists' responses; how visitors experience a dark tourism site very much depends upon their motives, cultural background and personal 
connection to the site (Cohen, 2011). Nevertheless, as Light (2017: 288) observes, studies of dark tourism experiences reveal that 'many visitors are more deeply engaged than they have been given credit for, and their visits are opportunities for connection, understanding and meaning-making'. Thus, not only does this research concur with earlier studies but it also suggests that particular forms of interpretation, such as the photograph in L'Aquila, may actually stimulate feelings and emotions that may have otherwise remained dormant.

\section{ii. Personal reflection}

As discussed above, the more recent approach to photographing conflict, war and other forms of human suffering that offers interpretations rather than (often graphic) documentary images encourages a more proactive role on the part of the viewer. That is, the viewer is obliged to interpret a picture and its inherent message not through the lens of the camera that captured the image but through the lens of their own knowledge and experience, their own lifeworld (Batchen, Gidley, Miller \& Prosser, 2012).

Such a process was clearly evident in the comments of a number of respondents who revealed that gazing on Grillo's image inspired them to consider the tragedy of L'Aquila from a reflective stance. As one respondent put it, 'You think of your own family, your own life, images like this help you to connect'. Another explained her feelings at greater length:

Do you know what I thought and how I interpreted this image? It makes one sad, it makes one think that people cry for those that are no longer here. That's clear from the clothes, empty, missing, it's a bit haunting, ghostly like, very much in keeping with the rest of this city, the atmosphere. It makes me feel really bad, its painful to look at, hard to imagine what happened here, all the suffering, the poor family, what they must have gone through, experienced, and still, the moments on their own, in those moments of silence, what they must think, reflect on, what could have been. This photo is very moving and me being a mother, it makes me contemplate, what if this was me, my life, my family, my loss.... The image gets you thinking about so much, you ask yourself, where are all the people, how are they, not just physically but mentally, how have they managed to continue living, where are they living after all this time? What will happen to this place, what will it be like once, and it will be a long time, but when it is re-built, how different will it be? (Participant 10)

As such, these comments add weight to the argument that dark tourism sites may play a mediating role not only between the visitor and the 'dark' event in general, facilitating 
contemplation of the death of others (Sharpley \& Stone, 2008), but also encourages what Stone (2012) describes as personal 'mortality mediation'. In other words, 'the increasingly socially acceptable tourist gaze upon death and its reconceptualisation through dark tourism... offers the Self a practical contemplative mechanism to help neutralise the impact of mortality' (Stone, 2012: 1572). Whether or not this is indeed a common outcome of visiting a dark site is unclear; certainly, none of the respondents in this study indicated that the photograph stimulated personal reflection on their own mortality although it did encourage contemplation amongst some of their life, their family, and the life that others (the victims of the earthquake) might have had. Hence, this research suggests that visitors to dark sites reflect more on life and the living than on death and mortality, as other research has also found. For example, in their study of genocide tourism in Rwanda, Sharpley and Friedrich (2016) identified 'hope' as a common emotion experienced by visitors.

Interestingly, for one visitor (an Italian domestic tourist), seeing the photograph not only led him to question the continuing and much criticised disaster recovery process in L'Aquila but also to reflect on his own lack of support for the city and its inhabitants:

This photo is so powerful. For me it does not only offer $m$ an insight into the people in the image, but it makes me think, or at least begin to consider, how many others have suffered so much, how many others have been left in such difficult and painful and changed worlds after so many years... the city is still so ruined. However, when I looked at this image, it also made me feel angry, angry about the lack of effort and support provided to the people of this city, about the corruption. There was a report of a construction company, the owner had his phone tapped and he was reported as laughing at how much money he would make from this disaster. Then I look at this image, how can you laugh when you think of the suffering that has taken place... at times like this, when people lose their loved ones, money has very little value, if any. It actually makes me feel bad. I question my own support, be it financial support, a voice of support, anything. Being here now and seeing this, I ask myself, could I have done more, why did I not do more? (Participant 5)

\section{iii. The photograph: interpreting the disaster}

As observed above, since 2009, L'Aquila has continued to attract tourists who come to wander the streets of the still ruined city centre, albeit in smaller numbers than in the immediate aftermath of the earthquake. Nevertheless, few if any forms of interpretation exist in the city to facilitate the visitor experience and, in particular, to convey some sense of 
human disaster that lies hidden behind the ruined buildings. Hence, for some respondents, the photograph played a valuable interpretative role, providing some deeper meaning and understanding than that conveyed by the remaining physical evidence of the disaster. This role is perhaps best summarised by one respondent who said:

This image helps to contextualise what has happened, especially because walking around the city, there is little to help me as a tourist to understand what has happened, other than the massive destruction that can be seen from the buildings... The message in this photo is great - to me it says... stop, have a look, have a look at what I have suffered, what is left of what used to be my life. Of course, you have to move one, new challenges, a different life, but this really makes you think about how drastically and how quickly everything can change. In a few moments, everything has changed for this man and his son, everything. If this does not resonate with people's emotions when looking at it, what will? What is powerful about this photo is the people... I think it brings a stronger sense of unity, because I can relate more to the people than the ruins. (Participant 2)

At the same time, however, whilst recognising the intrinsic message conveyed by the photograph, a number of respondents lamented the lack of explanation or information provided with it (the photograph is displayed with no explanatory details provided concerning its content). For some, this to some extent diminished the overall impact of the image although it still conveyed a powerful message:

Whilst the image offers some narrative, it still leaves much to individual interpretation. There is no written explanation of who the family are, what they have lost, there are no names, identities, ages... so only so much can be interpreted. I would have to do more research on the photo, maybe online to see if I can find out who this is... maybe this was the photographers intention. If you saw this in a museum, maybe it would come with some written explanation to bring me closer to the people, their experiences... maybe this is what is missing, maybe this would for me have a stronger impact. But still, it is clear that this is a photo that invites you to engage and to consider more what has happened here and to the local people. (Participant 8)

For others, conversely, the lack of explanatory text accompanying the photograph rendered it relatively meaningless. In other words, reflecting the argument that some forms of photograph are evidential of a story told in written words (Price, 1994), some tourists, particularly those who displayed less positive engagement with the photograph, explained this on the basis of the lack of textual explanation: 
If there was more written explanation provided with this image, then maybe this photo would have provided more meaning for me. I would like a story, some interpretation. Maybe this photo would be well placed in a museum with other photos, in a gallery, which clearly tells the story of the people. But, the more I look at it, it is still a moving photo. (Participant 14)

This photo did not pull me in, it does not tell me too much. It has very little explanation; I think it would be more powerful, more captivating if it had some written information. Maybe a plaque, here that offers a more detailed story of who the people are, what happened to them, where was the actual house in the city.., Otherwise, at least for me, it is easy to just walk past it. A moments gaze but not enough to draw me in. (Participant 17)

When you walk around the city, there is not much information for tourists. A lot of things are left to self-interpretation, this photo included. I do not know this man, this boy, their life, what happened. Some more information would help me understand more. (Participant 13)

\section{iv. Scale of the disaster}

Whilst the lack of a written narrative explaining the photograph was given by a number of tourists for the lack of engagement with it, some also spoke more generally about the wider context of the disaster in L'Aquila. That is, given the enormity of the disaster, still evident in the extent of the ruined city centre, they found it difficult to focus on the photograph, to attempt to engage with it in any meaningful way, as just one story within a wider tragedy.

Why did I not stop to look at this photo? To be honest I am not sure. There is a lot to take in, and I guess that at the moment, I am finding it hard to understand what happened here. There is so much destruction everywhere, I guess that it is easy for some things, like this photo, to blend into the background. (Participant 20)

I did not really take the image in. We have been walking around for over an hour and, to be honest, I am a bit overwhelmed. The extent of the disaster is so overwhelming. It's all a bit too much and somewhat disorientating. Having not visited and having little prior knowledge of this city, it's hard to imagine what it was like before, so I am inclined to make up my own stories and ideas. I am just walking about in awe of the scale of the damage and how empty all the buildings and shops are. So some things are easily missed. I think that is why I might have not stopped and looked at this photo, it blended in a bit. Plus, I do not know the people in the image, there is nothing explaining 
who the people are. I can see what is in the image, but I do not know these people. I do not need this image to imagine the scale of the damage and the amount of suffering that has taken place, I can see it, it is all around me. (Participant 14)

Such responses both concur with and contradict other dark tourism research. That is, it has been found that the scale of some disasters or tragedies are too vast to understand, that the extent of human suffering paradoxically de-humanises the event yet, at the same time, photographs of victims, particularly children, serves to emphasise the human dimension of a large-scale disaster (Sharpley, 2014). In the case, however, the photograph did not, for some respondents, fulfil this function, perhaps supporting the argument that, in a contemporary world replete with photographic images, people are rarely conscious of what is on display around them. In other words, the extent to which an observer is likely to engage with a photograph depends on the context or location in which it is encountered. For example, Bate (2016) suggests that a photograph displayed in a gallery or museum will more likely gain the viewer's attention than in other non-specific locations. However, the ruined centre of L'Aquila can, in a sense, be considered a 'museum' and, hence, when asked if Grillo's photograph (which was originally displayed in a gallery) is appropriately placed in city centre, in the midst of the disaster which it seeks to interpret, a number of respondents revealed a positive attitude to its location, in particular as a focus for tourists visiting the city:

The photo is very moving and I imagine that many people must stop and look. Especially with it being here, on this central street, a busy street, many people must pass and look at it. You would expect that people will react differently, but at least they react, at least they look and contemplate what has happened, this is what is important... the photo connects the viewer with the people, the event. (Participant 11)

It is here, in the city, that people can really see the damage of this earthquake. And it is here that the stories should be told, expressed and understood. It is normal, I think, that places where the event occurred should showcase stories, messages, experiences. It happens in many places, at least over time, you can see it New York. This is a bit different, almost the entire city is ruined. But still, I think that stories, writing or photos are more effective in the place where the events took place, especially when there is tragedy, especially of this scale. Not many people have experienced such tragic events, so one needs to visit the places to really understand and experience it. (Participant 9)

I am a tourist in this city. I have come to see what has happened here, and, therefore, I want to 
learn and understand; my eyes are open to what has happened, my mind eager to learn, that is why I am here. If this photo were somewhere else, in a different city, maybe I would not have looked at it, especially if I was busy, but the fact that I am here means that I am interested. So I think it is normal to share such stories with tourists of what has happened. I am surprised that there is not more. But the photo is much more important here in the city as it is part of the event, a consequence of the earthquake, and people need to know and see this, so here is where it should be displayed. I am not saying it should not be displayed elsewhere, but here it should be, and other photos, because they help people to understand. (Participant 12)

\section{v. The authenticity of the photograph}

Finally, acknowledging the 'reality or representation' debate referred to above, the research sought to establish the extent to which the tourists / respondents considered the photograph in L'Aquila to be an authentic interpretation of the disaster. In other words, as an 'artistic' photograph composed by the photographer and taken some time after the event as opposed to a documentary record of the actual earthquake, did it present a realistic interpretation or was it, for the tourists, more of an artistic representation, albeit a powerful one? It should be noted here that, given the lack of information provided to tourists about it, during the interviews the interviewer provide details about the photograph. This included details about the photographer, not least because, as suggested in the literature, photographs documenting such an event are considered to be more authentic if taken by a local rather an outsider (Wells, 2015).

Overall, the responses suggested that, certainly in the case of the photograph that is the focus of this research, the distinction between reality and representation, between documentary and art, is blurred. Many of the respondents recognised the photograph as a carefully constructed, staged image and, as such, as an artwork. At the same time, however, knowing of the loss suffered by the father and son in the photograph brought, for many respondents, a painful reality to it, reality that perhaps makes the image more powerful. As one respondent discussed:

Art is very personal and people interpret art in their own ways. And this photo is a work of art. It is art because the photographer has created an image. This is not real in the sense that he has captured it in the moment; it is staged, there has been a process to reaching this type of image, the angle of the camera, taking a bird's eye view shot, the layout of the bed, the people, the choice of clothing, everything has been created to purposefully generate an emotional reaction from whoever 
views this image. So is this image real, not literally, but in the sense of what has happened, yes, it is clear that there is great loss, as a result of the earthquake. I think the photographer has created a frame in which people can connect or at least interpret that these people in the image have lost loved ones. You tell me this is a local photographer taking a photo of his friend and his son who lost their mother and daughter... this makes sense and makes it even more real and emotional. The fact that the photographer is local as well, for me makes it better, more genuine... I wonder what it must have been like for the local and his son to actually take part in this. I guess it was easier because they were friends, I don't know. (Participant 11)

For another, the photograph is too staged, yet nevertheless fulfils its purpose

Talking about art is very difficult. The meaning and representation of art is very different for everyone. But the image itself offers an idea that a lot has been lost, because in the image, there are no walls, the earth, no physical structure, two bed frames, its clearly an image that portrays loss. But what I do not like about the photo is how the clothes are draped onto the beds, this makes it less natural. For me it is a little bit too staged. But that does not take way the fact that the image has the ability to make you realise that people have lost a lot here. (Participant 7)

\section{Conclusion}

A number of conclusions can be drawn from the research into tourists' responses to the photograph in l'Aquila. First, for the majority of tourists, as a constructed image of the disaster, representing it through the loss of one man and his son, the photograph was considered to be a more effective means of connecting the viewer with the human dimension of the tragedy than more traditional documentary-type photographs. Certainly, the latter play an important role in, by definition, documenting the effects of a natural disaster, such as an earthquake. However, the research revealed that tourists in L'Aquila confirm the belief that modern society has become immune to pictures documenting disaster and human suffering. However, through Grillo's photograph, tourists were not only able to empathise with the earthquake's victims, but were also encouraged to reflect on the disaster within their own personal context. As such, this research confirms the outcomes of other work within the dark tourism domain, that tourists may engage at both a conative and affective level with dark sites. However, such engagement is not always immediate; that is, in certain contexts, such as a natural disaster sites, a catalyst may be required to stimulate an emotional response.

Second, there was general support for the positioning of the photograph in the ruined 
city centre. Not only was it a rare source of interpretation of the disaster within the city but is also helped tourists to make some sense of the ruined buildings around them. Thus, together with the affective response of tourists to the photograph, the research suggests that, dependent on context, representational photographs can play an important role in enhancing and deepening the visitor experience at disaster and other dark sites.

Nevertheless, third, a majority of respondents suggested that, although in itself a powerful image, its message have been more effectively conveyed with the addition of some explanatory text. That is, knowledge of the circumstances under which the photograph was taken, of who the father and son were, would have endowed it with even greater significance, as one respondent observed: 'I think the meaning in the photo is more powerful than the photographer; it is the people and what is being presented that is important, the message that they are trying to share. This is important; this is what people should take from the image'. Thus, even though essentially artistic, the photograph has a meaning, a foundation, based in the reality of one family's suffering, knowledge of which can only serve to enhance its affective message.

Of course, the context of L'Aquila is unique, not least in the willingness of a local family to co-operate with a local photographer to produce an image such as that explored in this research. Hence, the issues raised in this paper demand further research, not least into how tourists respond to different kinds of photographs at other dark tourism sites. It may be, for example, that in some circumstances a documentary-type photograph offers a more powerful or poignant representation. Equally, further research may determine if a relationship exists between the immediacy of the event and photographic representations. For example, Lennon and Foley's (2000) assertion that dark tourism is essentially a modern phenomenon, relating only to events within living memory, could further explored through the context of photographic interpretation. Moreover, further research could explore the varying effects of different photographic content; is it, for example, images of people (and, as some suggest, specifically children) that evoke the most emotional response amongst visitors?

Despite the uniqueness of this study and the opportunities for further research, it can nevertheless be concluded that repesentational photographs can, according to the results of this research, be a powerful interpretative tool at disaster tourism sites, especially if supported with explanatory text. Specifically, they may contribute to a more meaningful, less voyeuristic experience, as summed up by one respondent: 
But then you see an image like this, where you see humans, people who are real, it is clear what is being presented. It's heavy, a little dark, but it's real; this is the true story of this earthquake. For me, for a tourist, this is what really brings me closer to the reality of this tragedy. Being here in the city and seeing images like this, it really is something else. (Participant 9)

Acknowledgement: The authors are grateful to Roberto Grillo for permitting the use of his photograph and, in particular, to Vincenzo Vittorini who appears in the photograph with his son, for his support for this research. 


\section{References}

Ashworth, G. and Hartmann, R. (2005) Horror and Human Tragedy Revisited: The Management of Sites of atrocities for Tourism. New York: Cognizant Communication Corporation.

Barkun, M. (1974) Disaster and the Millennium. New Haven, Conn.: Yale University Press.

Batchen, G., Gidley, M. Millar, MN. And Prosser, J. (eds.) (2012) Picturing Atrocity: Photography in Crisis. London: Reaktion Books.

Bate, D. (2016) Photography: The Key Concepts, $2^{\text {nd }}$ Edition. London: Bloomsbury.

Berger, J. (2013) Understanding a Photograph (edited / introduced by G. Dyer). London: Penguin Books.

Blom, T. (2000) Morbid tourism - A postmodern market niche with an example from Althorp. Norsk Geografisk Tidsskrift (Norwegian Journal of Geography), 54(1), 2936.

Bourdieu, P. (1996) Photography: A Middle-Brow Art. Cambridge: Polity.

Bornefeld, W. (1996) Time and Light. Stone Mountain, GA.: White Wolf Publishing.

Braun, V., and Clarke, V. (2006). Using thematic analysis in psychology. Qualitative Research in Psychology, 3: 77-101.

Brotherton, B. (2015). Researching Hospitality and Tourism. (Second Edition). London: Sage.

Brown, L. (2014) Memorials to the victims of Nazism: The impact on tourists in Berlin. Journal of Tourism and Cultural Change, 13(3), 244-260.

Butler, J. (2005) Photography, war, outrage. PMLA, 120(3), 822-827.

Chronis, A. (2012) Between place and story: Gettysburg as tourism imaginary. Annals of Tourism Research, 39(4), 1797-1816.

Coats, A. and Ferguson, S. (2013) Rubbernecking or rejuvenation: Post-earthquake perceptions and the implications for business practice in a dark tourism context. Journal of Research for Consumers, 23(1), 32-65.

Cohen, E. (2011). Educational dark tourism at an in populo site: The Holocaust Museum in Jerusalem. Annals of Tourism Research, 38(1), 193-209. 
Contreras, D., Blaschke, T., Kienberger, S. and Zeil, P. (2014) Myths and realities about the recovery of $\mathrm{L}^{\prime}$ Aquila after the earthquake. International Journal of Disaster Risk Reduction, 8, 125-142.

Edwards, E. and Mead, M. (2013) Absent histories and absent images: photographs, museums and the colonial past. Museum and Society, 11(1), 19-38.

Edwards, S. (2006) Photography: A Very Short Introduction. Oxford: Oxford University Press.

Flamminio, C. (2009) Tourism over the rubble of the earthquake in L'Aquila. Available at: http:// www.demotix.com/photo/tourism-over-rubbles-earthquake-laquila124762 (Accessed 13 October 2010).

Foley, M. and Lennon, J. (1996) JFK and dark tourism: A fascination with assassination. International Journal of Heritage Studies, 2(4), 198-211.

Frew, E. (2017) From living memory to social history: commemoration and interpretation of a contemporary event. In G. Hooper and J. Lennon (eds) Dark Tourism: Practice and Interpretation. Abingdon: Routledge, pp. 160-173.

Friedrich, M. \& Johnston, T. (2013) Beauty versus tragedy: Thanatourism and the memorialization of the 1994 Rwandan Genocide. Journal of Tourism and Cultural Change, 11(4), 302-320.

Gillham, B. (2005). Research Interviewing: The Range of Techniques. Maidendhead, McGraw-hill Education.

Gould, K. and Lewis, Y. (2007) Viewing the wreckage: Eco-disaster tourism in the wake of Katrina. Societies Without Borders, 2(2), 175-197.

Grillo, R. (2012) L'(Est)Etica del Deolore: Phographie. Colonnella, Abruzzo: Grafiche Martintype.

Grillo, R. and Vitturini, R. (2009) Terrae Motus: Ore 3.32 L'Aquila 6 Aprile '09. L 'Aquila, Abruzzo: Marte Editrice.

Gye, L. (2007) Picture this: The impact of mobile camera phones on personal photographic practices. Continuum: Journal of Media \& Cultural Studies, 21(2), 279-288.

Haldrup, M. and Larsen, J. (2010) Tourism, Performance and The Everyday: Consuming the Orient. Abingdon: Routledge.

Holiday, S., Lewis, M.J., Nielsen, R., Anderson, H.D. and Elinzano, M. (2016) The selfie study: Archetypes and motivations in modern self-photography. Visual Communication Quarterly, 23(3), 175-187. 
Hughes, R. (2008) Dutiful tourism: Encountering the Cambodian genocide. Asia Pacific Viewpoint, 49(3), 318-330.

InAbruzzo (2009) Il terremoto diventa attrattore turitico (The earthquake become a tourism attraction). Available at: http://www.inabruzzo.com/?p=10646. (Accessed 14 October 2011).

Kelman, I. and Dodds, R. (2009) Developing a code of ethics for disaster tourism. International Journal of Mass Emergencies and Disasters, 27(3), 272-296.

La Grange, A. (2005) Basic Critical Theory for Photographers. Oxford: Focal Press/Elsevier Lennon, J. (forthcoming) Dark tourism visualisation: Some reflections on the role of photography. In P. Stone et al (eds) The Palgrave Handbook of Dark Tourism Studies. London: Palgrave Macmillan.

Lennon, J. and Foley, M. (2000) Dark Tourism: The Attraction of Death and Disaster. London: Continuum

Light, D. (2017) Progress in dark tourism and thanatourism research: An uneasy relationship with heritage tourism. Tourism Management, 61, 275-301.

Logan, W. and Reeves, K. (2008) Places of Pain and Shame: Dealing with 'Difficult Heritage'. Abingdon: Routledge.

Long, J. (2008). Researching Leisure, Sport and Tourism, The Essential Guide. London: Sage.

Mason, P. (2014). Researching Tourism, Leisure and Hospitality for your Dissertation. Oxford: Goodfellow Publishers.

Mostafanezhad, M. (2014) Volunteer tourism and the popular humanitarian gaze. Geoforum, 54, 111-118.

Nickel, D. (2001) History of photography: The state of research. The Art Bulletin, 83(3), 548558.

Oosterwijk, S. (2004) Of corpses, constables and kings: The Danse Macabre in late medieval and Renaissance culture. Journal of the British Archaeological Association, 157(1), $61-90$.

Price, M (1994) The Photograph: A Strange, Confined Space. Stanford, CA: Stanford University Press.

Quarantelli, E. (1985). What is disaster? The need for clarification in definition and conceptualization in research. In B. Sowder (eds), Disasters and Mental Health: 
Selected Contemporary Perspectives. Washington, DC: US Government Printing Office, pp. 41-73.

Raine, R. (2013) A dark tourist spectrum. International Journal of Culture, Tourism and Hospitality Research, 7(3), 242-256.

Robins, C. (1984) The Pluralist Era: American Art 1968-1981. New York: Harper Row.

Rojek, C. (1997) Indexing, dragging and the social construction of tourist sites. In C. Rojek and J.Urry (eds), Touring Cultures: Transformations of Travel and Theory. London: Routledge, pp. 52-74.

Scarles, C. (2009) Becoming tourist: Renegotiating the visual in the tourist experience. Environment and Planning D: Society and Space, 27(3), 465-488.

Schaller, D. (2007) From the editors: Genocide tourism - educational value or voyeurism? Journal of Genocide Research, 9(4), pp. 513-515.

Sharpley, R. (2014) Tourist experiences of genocide sites: The case of Rwanda. Paper presented at Belgrade International Tourism Conference, College of Tourism, Belgrade, 27-29 March.

Sharpley, R. and Friedrich, M. (2016) Genocide tourism in Rwanda: Contesting the concept of the 'dark tourist'. In G. Hooper and J. Lennon (eds), Dark Tourism: Practice and Interpretation, Abingdon: Routledge, pp. 134-146.

Sharpley, R. and Stone, P. (2009) The Darker Side of Travel: The Theory and Practice of Dark Tourism. Bristol: Channel View Publications.

Shondell Miller, D. (2008) Disaster tourism and disaster landscape attractions after Hurricane Katrina: An auto-ethnographic journey. International Journal of Culture, Tourism and Hospitality Research, 2(2), 115-131.

Sion, B. (2014) Death Tourism: Disaster Sites as Recreational Landscape. London? New York: Seagull Books.

Sontag, S. (2004) Regarding the Pain of Others. London: Penguin Books.

Sontag, S. (2008) On Photography. London: Penguin Books

Stone, P. (2006) A dark tourism spectrum: Towards a typology of death and macabre-related tourist sites, attractions and exhibitions. Tourism: An Interdisciplinary International Journal, 54(2), 145-160.

Stone, P. (2012) Dark tourism and Significant Other death: Towards a model of mortality mediation. Annals of Tourism Research, 39(3), 1565-1587.

Stylianou-Lambert, T. (2012) Tourists with cameras: reproducing or producing? Annals of Tourism Research, 39(4), 1817-1838. 
Tarlow, P. (2005) Dark tourism: The appealing side 'dark' side of tourism and more. In M. Novelli (ed.), Niche Tourism: Contemporary Issues, Trends and Cases. Oxford: Elsevier, pp. 47-57.

Tierney, K., Lindell, M., and Perry, R. (2001) Facing the Unexpected: Disaster Preparedness and Response in the United States. Washington, DC: Joseph Henry Press.

Thomas, G. and Morgan-Watts, M. (1988) Shipwreck: The Strange Fate of the Morro Castle. Dorchester: Dorset Press.

Thurnell-Read, T. (2009) Engaging Auschwitz: An analysis of young travellers' experiences of Holocaust tourism. Journal of Tourism Consumption and Practice, 1(1), 26-52.

Trachtenberg, A. (1985) Albums of war: On reading Civil War photographs. Representations, 9, 1-32.

UNISDR. (2009) Terminology in Disaster Risk Reduction. Geneva: United Nations International Strategy for Disaster Reduction.

Uzzell, D. (1992) Interpretation of war and conflict. In D. Uzzell (ed.) Heritage Interpretation: The Natural \& Built Environment. London: Bellhaven Press, pp. 3347.

von Vacano, M. and Zaumseil, M. (2013) Understanding disasters: An analysis and overview of the field of disaster research and management. In M. Zaumseil, S. Schwartz, M. von Vacano, G. Sullivan, and J. Prawitasari-Hadiyono (eds), Cultural Psychology of Coping with Disasters: The Case of an Earthquake in Java, Indonesia. New York: Springer-Verlag, pp. 3-44.

Wells, L. (ed.) (2003) The Photography Reader. London: Routledge.

Wells, L. (2015) Photography: A Critical Introduction, $5^{\text {th }}$ Edition. Abingdon: Routledge.

Williams, P. (2004) Witnessing genocide: vigilance and remembrance at Tuol Sleng and Choeung Ek. Holocaust and Genocide Studies, 18(2), 234-254.

Van House, N. (2011) Personal photography, digital technologies and the uses of the visual. Visual Studies, 26(2), 125-134.

Van Hoving, D., Wallis, L., Docrat, F. and De Vries, S. (2010) Haiti disaster tourism: A medical shame. Prehospital and Disaster Medicine, 25(3), 201-202.

Yan, B.J., Zhang, J., Zhang, H.L., Lu, S.J. and Guo, Y.R. (2016) Investigating the motivation-experience relationship in a dark tourism space: A case study of the Beichuan earthquake relics, China. Tourism Management, 53, 108-121. 
Figure 1: The photograph in situ, L'Aquila

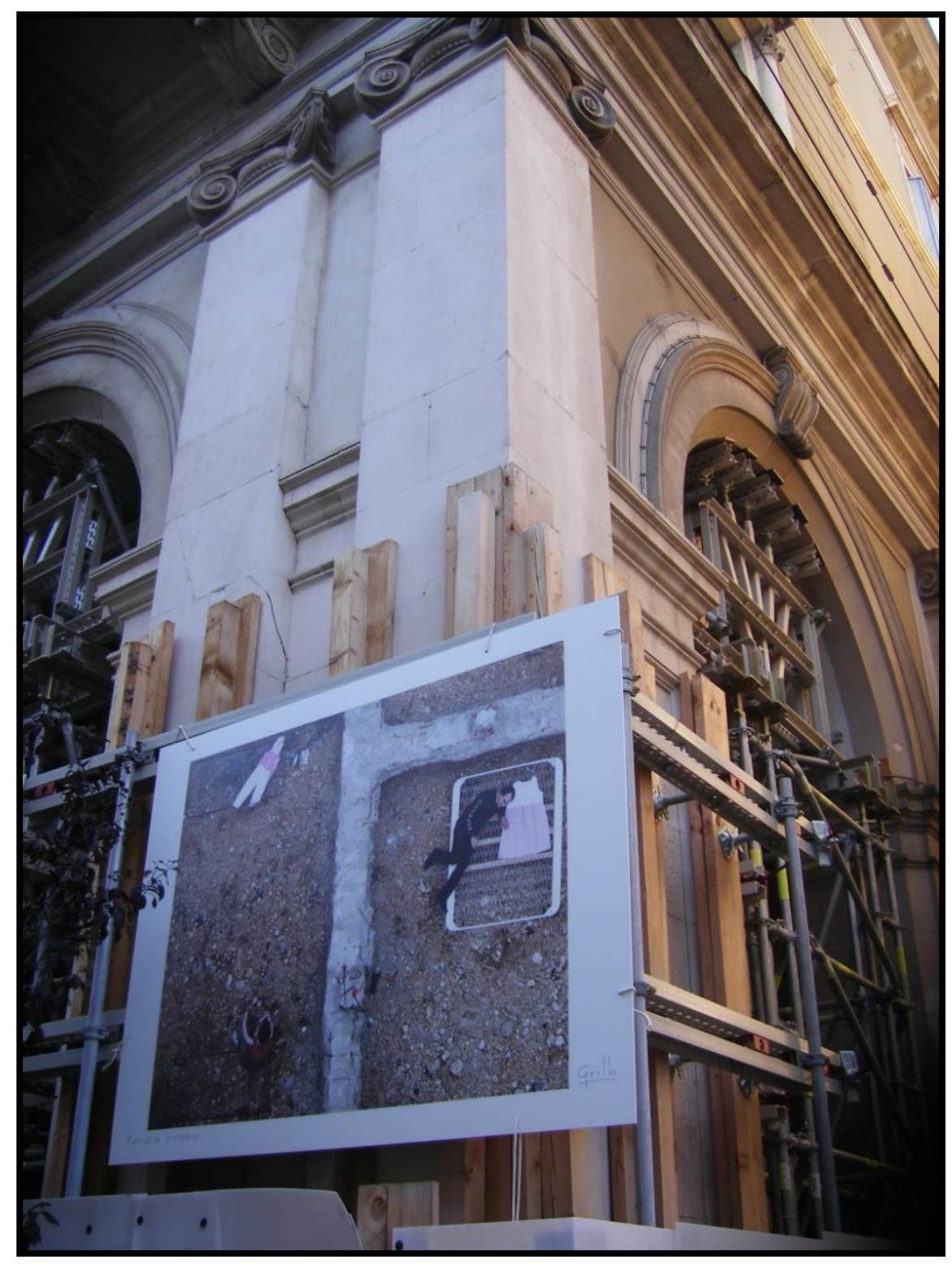

Source: Author 
Figure 2: The photograph

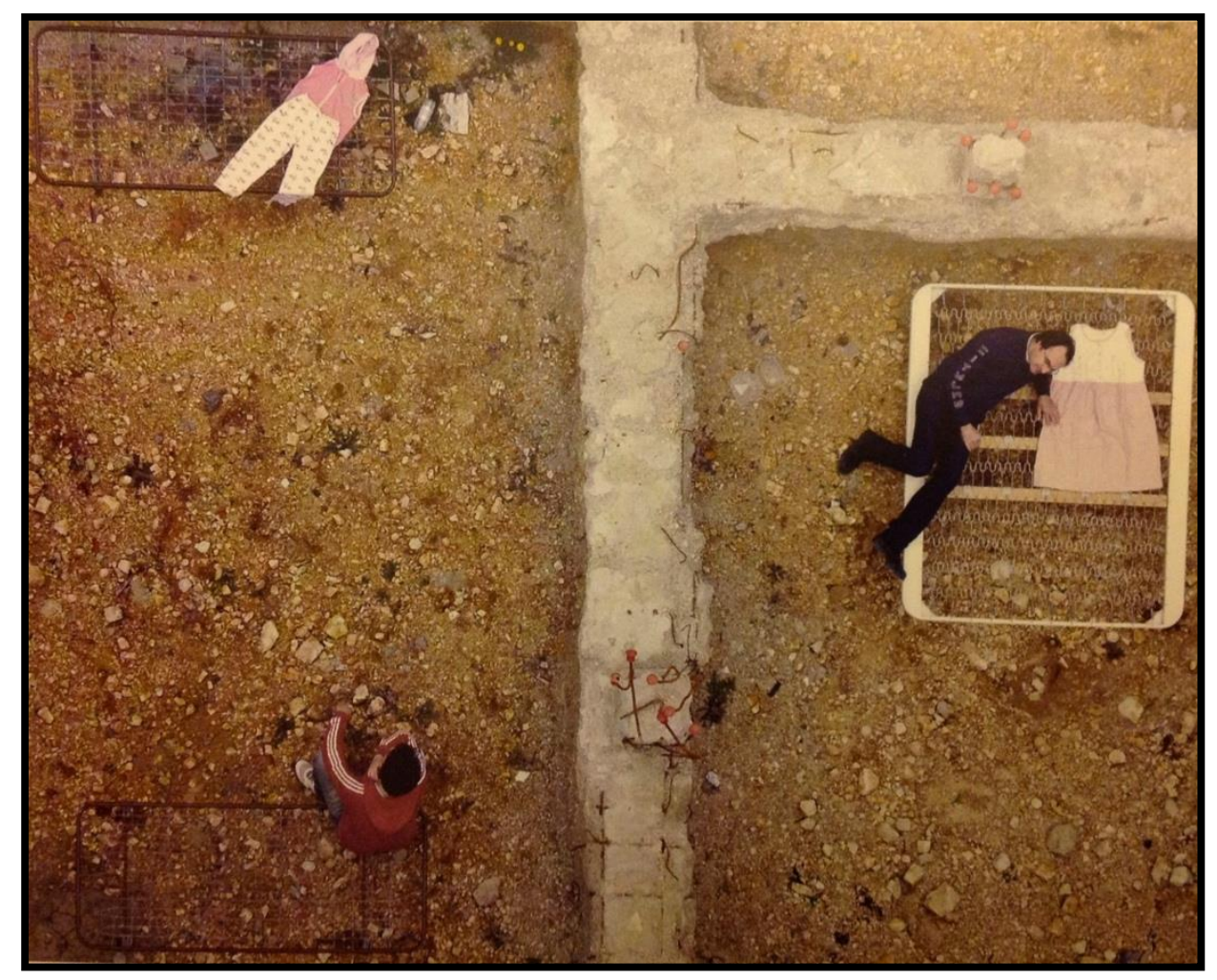

Source: Grillo (2012) Reproduced with the permission of the photographer 
Table 1: List of participants

\begin{tabular}{|c|c|c|}
\hline Participant: Tourist & $\begin{array}{c}\text { Gender } \\
\text { M/F }\end{array}$ & Nationality \\
\hline 1 & M & Holland \\
\hline 2 & M & Italy \\
\hline 3 & M & Italy \\
\hline 4 & I & Italy \\
\hline 5 & F & Italy \\
\hline 6 & M & Switzerland \\
\hline 7 & F & Switzerland \\
\hline 8 & F & Italy \\
\hline 9 & M & Italy \\
\hline 10 & F & Belgium \\
\hline 11 & M & Belgium \\
\hline 12 & M & France \\
\hline 13 & F & England \\
\hline 14 & F & England \\
\hline 15 & M & Italy \\
\hline 16 & M & Italy \\
\hline 17 & M & Germany \\
\hline 18 & F & Germany \\
\hline 19 & F & Germany \\
\hline 20 & M & \\
\hline & & \\
\hline
\end{tabular}

